\title{
In Search for Anchors The Fundamental Motivational Force in Compensating for Human Vulnerability
}

\author{
Bagus Riyono \\ Universitas Gadjah Mada, Yogyakarta \\ Fathul Himam \\ Universitas Gadjah Mada, Yogyakarta \\ Subandi \\ Universitas Gadjah Mada, Yogyakarta
}

\begin{abstract}
The purpose of this study is to develop a new integrative theory of motivation drawn from the existing theories and data. The method used is a combination of meta-ethnography and grounded theory. The second phase of the study employed a thought experiment to test the newly developed theoretical propositions of motivational force. The first phase of the study revealed a central phenomenon for the occurrence of motivational force, i.e. "In Search for Anchors," which is a result of the paradox between freedom to choose and human vulnerability. "Freedom to choose" is the central factor of a motivational model that includes "urge," "challenge," "incentive," and "meaning." These five factors are motivational sources, which have holistic-dynamic-integrative interaction. Human vulnerability is the other side of the motivational model that comprises risk, uncertainty, and hope that ignite motivational force. The dynamic interaction of risk, uncertainty, and hope is represented in a mathematical formula that produces the strength of the force, $(\mathrm{R}-\mathrm{H}) 2 \mathrm{x} \mathrm{U}$, which can be potrayed in a "twin-peak" curve. The thought experiment was conducted to test the hypothetical formula. The result shows that the "twinpeak" hypothesis is supported but the shape of the curve is found to be not symmetrical. The data show that hope is the strongest motivational force, therefore the formula is modified into $=(\mathrm{R}-\mathrm{U}) 2 \times \mathrm{H}$. The implication of the study and the utility of the new theory are discussed.
\end{abstract}

\begin{abstract}
Abstrak: Penelitian ini bertujuan untuk mengembangkan sebuah teori motivasi baru yang integratif, yang disusun berdasarkan teori-teori yang sudah ada dan data-data penelitian yang telah tersedia. Untuk itu diaplikasikan sebuah metode yang merupakan gabungan dari meta-ethnography dan grounded theory. Pada tahap ke dua dari studi ini, dilakukan eksperimen dengan metode thought experiment untuk menguji proposisi teoritis dari teori yang baru dirumuskan mengenai motivational force. Pada tahap pertama, studi ini mengungkap sebuah fenomena sentral untuk terjadinya motivational force, yaitu "In Search for Anchor," yang merupakan sebuah resultan dari sebuah paradoks antara freedom to choose dan buman vulnerability. "Freedom to choose" adalah faktor utama dari model motivasi yang mencakup "urge," "challenge," "incentive," dan "meaning."
\end{abstract}


Kelima faktor tersebut adalah merupakan sumber-sumber motivasi, yang memiliki sifat hubungan yang "bolistic-dynamic-integrative." Human vulnerability (ketidakberdayaan manusia) adalah sisi lain dari model motivasi tersebut yang terdiri dari risk, uncertainty, dan hope, yang memicu kekuatan motivasional (motivational force). Dinamika interaksi antara risk, uncertainty, dan hope dapat direpresentasikan oleh rumus matematis yang menghasilkan kekuatan motivasional, yaitu: $(\mathrm{R}-\mathrm{H})^{2} \times \mathrm{U}$, yang dapat digambarkan ke dalam kurva yang berpuncak ganda. Thought experiment dilakukan untuk menguji rumus hipotetis tersebut. Hasilnya menunjukkan bahwa puncak ganda yang dihipotesiskan didukung data, namun ditemukan bahwa bentuk kurva tidak simetris. Data menunjukkan bahwa variabel hope merupakan faktor terkuat dalam persamaan tersebut sebagai kekuatan motivasional. Oleh karena itu rumus matematis mengenai kekuatan motivasional dimodifikasi menjadi $=(\mathrm{R}-\mathrm{U})^{2} \times \mathrm{H}$. Implikasi dari hasil studi ini dan kemanfaatan dari teori baru ini dijabarkan dalam bagian akhir artikel ini.

Keywords: anchor; challenge; force; freedom to choose; hope; motivation; risk; uncertainty; urge; meaning; incentive. 


\section{Introduction}

Historians and scholars of social sciences are competing to explain the phenomena of the emergence and advancement of civilizations. Classical explanations usually provide arguments about the geography, climate, and various other geopolitical reasons to trigger advancement of a nation (Khaldun 1377; McClelland 1961). In a more general context, the question that arises is "what kind of forces are able to drive a nation to catch up and race to get ahead?." Many countries in the world have shown surprising rapid progress. In the 1980s Japan astonished the world with the success of their economy which was able to defeat America (Kondo 1991); Korea in the 1990s showed their "claws" and was able to compete with Japan in the automotive and electronic industries, and the era of the 2000s was marked by China's "miracle" (Naisbitt and Naisbitt 2010).

Experts in social sciences (Khaldun 1377; McClelland 1961; Smith 1776; Weber 1930) agree that there is a force that drives people to go forward, both for their own success or collectively in building a civilization. History shows that nations in this world alternately rise and fall, in power and oppressed (Durkheim and Mauss 1971; Khaldun 1377).

The discourse about the force has four layers of analysis, namely natural force, sociostructural force, group force, and internal force. Psychology has focused on explaining the dynamics of the internal force. The individual is the main actor in the progress of human civilization. All other forces serve only as an antecedent that would eventually culminate in triggering the internal force. Interconnectivity between the four layers of these forces can be illustrated in Figure 1, and referred to as "Layers of forces."

The notion of the force in terms of human behavior is described by Kurt Lewin as follows: "Behavior on the part of a person is assumed to be the result of field of forces each of which has direction and magnitude" (in Vroom 1964: 18). In essence, the force is something that directs human behavior with a specific intensity and direction. The concept of the force in the discipline of psy-

Figure 1. Layers of Forces

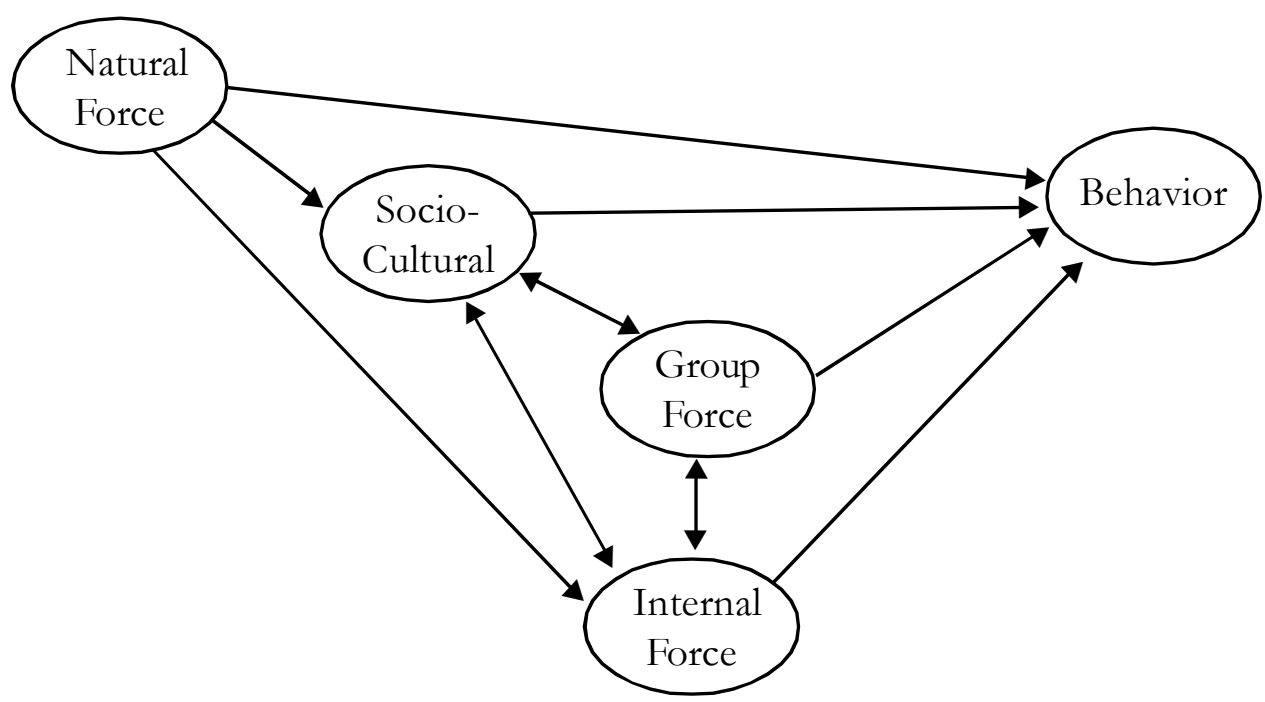


chology is implicitly included in the dynamics of motivation. However, motivation as a psychological construct has a broad meaning and scope. It is associated with other constructs that are considered as the underlying factors such as, "motive" (McClelland 1966; 1987; Atkinson 1957), "needs" (Maslow 1943), "goals" (Locke and Latham 1990), "reinforcement" or "feedback" (Komaki 1978; Komaki et al. 1982; Komaki 1986; Komaki et al. 1989; Komaki et al. 1986), and "valence" and "expectancy" (Vroom 1964; Wanous et al. 1983).

As a psychological construct, motivation has two meanings associated with the problems that will be solved. The first meaning of motivation is "something to account for an individual's selection of one path of action among a set of possible alternatives" (Atkinson 1957: 359). This first meaning is hereafter referred to as a "motivation as a choice." The second meaning of motivation is "the arousal or energizing of the organism. What conditions instigate action, determine its duration or persistence and finally its cessation. The phenomena to be explained include the level of activity of the organism and the vigor of amplitude of its behavior" (Vroom 1964: 2). This second meaning is, from now on, referred to as "motivation as a force" or simply "motivational force."

Until the beginning of this 21 st century, motivation was still ranked as the second most widely written about topic, after the topic of methodology (Cascio and Aguinis 2008; Latham and Pinder 2005). The journal articles that were reviewed showed that there is no common ground to explain what could be "responsible" for the emergence of human behavior. This problem has lasted for more than 40 years, since the 1960's (Vroom 1964) until recently (Latham and Pinder 2005).
Some of the issues concering the current motivation theories are elaborated in the following literature reviews.

Maslow's Need Hierarchy Theory is well known for its simplicity and intuitive notion of human nature. The fundamental proposition of Maslow's theory is: human behavior is driven by their needs. Here is Maslow's strong statement about the drive of human needs, "If we are interested in what actually motivates us, and not in what has, will, or might motivate us, then a satisfied need is not a motivator." (Maslow 1943: 393). Thus, according to Maslow, every form of human behavior is done in order to fulfil or to satisfy certain needs. Once these needs are satisfied they will no longer drive behavior, no longer motivate.

For Maslow everything about human behavior is driven by needs, even beyond the five basic needs. He also mentioned about the need for curiosity, aesthetic needs, etc, (Maslow 1943). However, Maslow faces a problem when he tries to explain "self-actualization."

\section{"The clear emergence of these needs rests upon prior satisfaction of the physiological, safety, love, and esteem needs. We shall call people, who are satisfied in these needs, basically satisfied people, and it is from these that we may expect the fullest (and healthiest) creativeness. (Maslow 1943: 383)"}

From Maslow's statement above, it can be implied that a self-actualized person is one who already fulfils all of their needs. It means that those people's behavior is not driven by the effort to fulfil their needs anymore. This statement contradicts the fundamental proposition of Maslow's theory, which is that only unsatisfied needs can motivate an individual's behavior. Maslow's idea about self-actualization is beyond human needs, but Maslow has 
not found a conclusive explanation for it. He wrote "it remains a challenging problem for research" (Maslow 1943).

The implication of Maslow's theory for application in the organizational setting is as follows. When management initiates an incentive program, with a range of different benefits, it can be understood from the perspective of needs theory. For example, in deciding what kinds of benefit should be offered to employees, management can consider the need level of the employees. For lower to middle level employees, the needs will include survival and safety, for example: food, housing, protection, etc. Then for the next level of needs they will appreciate some social gathering, social activities like "family day," etc. Above that, their esteem needs can be satisfied with programs such as "employee of the month," promotion and so on. However, it will be difficult for management to manage the employees who are already at the level of self-actualized person.

The other competing perspective on human motivation, which is widely applied in organizational setting, is the behavioral perspective, mainly based on Skinnerian theory of behavior modification (Skinner 1953). The basic assumption of the behavioral perspective is that human behavior occurs as a response to past experience. More specifically, reinforced past experience will shape future behavior, and reinforcement given to certain behavior will cause that behavior to persist. Skinner perceived a human being as "a machine" that can be programmed to go in a certain direction. Furthermore Skinner denied the existence of "free will" within human personality.

"It was not long before the additional step was taken...wbich produced the fully-fledged doctrine of 'man a machine',... machine has become lifelike and living organisms have been found to be more like machines." (Skinner 1953: 46)

The theoritical problem rests on the denial of the internal psychological dynamics, which represent the "fee will" of human beings. Actually the proposition of Skinnerian theory also explains that organisms possess what is called "random behavior," which is the original behavior before the organism experiences any reinforcement intervention. The notion of "random behavior" is similar to the characteristics of "free will," so actually Skinner cannot fully explain the dynamic of human behavior without considering the existence of "fee will." As a result of this denial, behavioral approach can only explain and predict human behavior within a limited context and time (Dipboye et al. 1994).

Skinnerian thinking has a strong influence on "scientific management perspective" or, according to McGregor, it is the basis for a "Theory X" perspective in managing human resources in an organizational setting. Even though a lot of critics already addressed these views of human behavior, the behavioral approach can be found even in recent management application such as in reward policy or performance management strategy. The problem arises when those strategies start to provoke protest among labor unions because they neglect the psychological wellbeing of the workers.

Idealistic theories assume that humans are basically good and always well behaved, which appears in the form of intrinsic motivation theories (Schulze and Frank 2003; Thompson and Thornton 2002; Vansteenkiste and Deci 2003; Weist et. al. 2001; Wood et al. 2000). Similar to self-actualization, intrinsic motivation is a beautiful and idealistic concept, but they face strong criticism from researchers who have at- 
tempted to investigate them empirically (Eisenberger and Cameron 1996; Eisenberger 1999; Payne 1970; Petri and Govern 2004; Lepper et al. 1999). Some other researchers recognize that the intrinsic and extrinsic motivation coexist in facilitaing behavior (Hoekman et al. 2005; Deci et al. 1999b; Lindenberg 2001; Xiang et al. 2005).

Other conflicting explanations for motivational force are between behavioral theories and cognitive theories, e.g. goal-setting theory. Goal-setting theory believes in internal forces in the form of goals and commitment, which are responsible for the emergence of motivated behavior (Latham and Baldes 1975; Locke 1980; Locke and Latham 1990). Goal-setting theory holds that the source of one's motivation is the presence of challenging goals that ignite passion to achieve them. By contrast, behaviorism argued that the motivation emerges when someone gets feedback on his work, which reinforces the individual to redo what they have done before (Komaki et al. 1978; Komaki et al. 1980; Komaki 1981; Komaki et al. 1989).

Confusion and contradictory propositions of achievement motivation theory, goal setting and VIE theory, are illustrated in Figure 2. Goal setting theory assumes that the strength of motivation will be higher with the smaller probability of success, while achievement motivation theory claims that a "middle way" is the best, when the probability of success is 50:50. On the other side, VIE theory claims that the higher probability of success will increase the strength of the motivational force. Each of the conficting theories has sound arguments and are supported by empirical data. It is not easy to explain these contradictions in terms of existing perspectives. Therefore, a new integrating theory is needed to solve the problems.

There are two possible explanations when there are three things that are contradictory, but each is claimed to be correct. The first possible explanation is that there is only

Figure 2. Conflicting Propositions of n-Ach, Goal-Setting, and VIE Theory

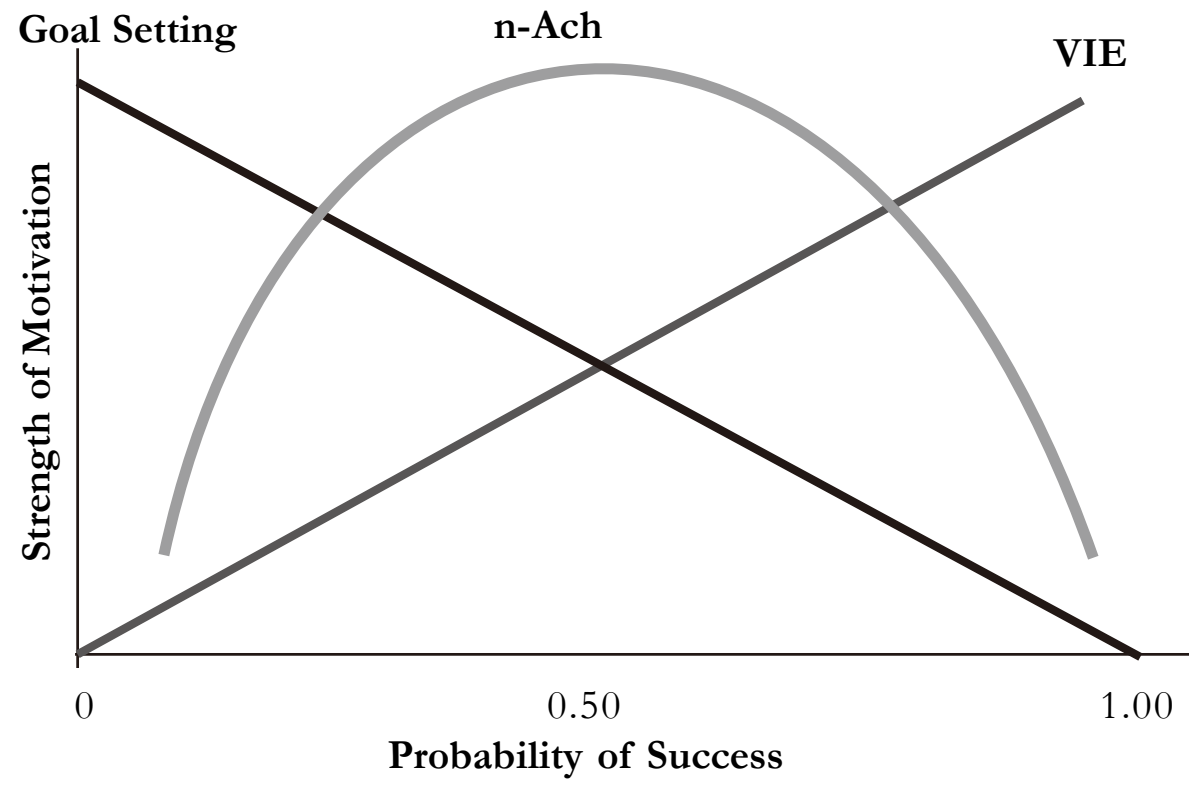


one correct theory and the others are wrong, so we need to strengthen the correct proposition with more evidence, and argue that the other ones are wrong, with sufficient evidence as well. The second possible explanation is that all theories could be correct, but each approached the phenomenon from different perspectives. It is like the metaphor of three blind men who were asked to describe an elephant. Each one found evidence but the evidence was understood or interpreted differently. In other words, each theory is only a fragment of the whole truth.

This study aims to dig deeper into the concepts about motivation in order to formulate a new theory about the force that is more essential (atomic theory), through a multi-paradigm and multi-method approach. This study will go beyond the level of understanding of the contemporary theories of motivation. This is done in order to find the underlying principles of motivational dynamics through de-construction and re-construction of psychological constructs concerning the motivational force. Thus, the research question is, "what kinds of psychological characteristics that are responsible for the emergence of motivational force?"

\section{Method}

This research was conducted by combining the approaches of radical humanist, interpretive, and functionalist (Gioia and Pitre 1990). Radical humanist approach through critical analysis of the established theories is conducted to gain a new perspective in understanding the dynamics of motivation and its supporting constructs. An interpretive approach is applied through analyzing primary data on experiences of motivated behavior, which are collected to obtain a deeper understanding of the dynamics of motivation.
A functionalist approach is applied to test the newly constructed theoretical proposition.

The meta-ethnography technique (Noblit and Hare 1988) is an appropriate technique to represent the radical humanist approach, namely to critically analyze and reinterpret the texts that have been formulated in the conventional theories of motivation, to understand the psychological characteristics of the motivated behavior. The expected outcome of this procedure is the formulation of the psychological characteristics associated with the emergence of the force in the dynamics of motivated behavior.

An interpretive approach was used by conducting grounded theory research (Strauss and Corbin 1990), namely to understand the characteristics of the psychological situation of motivated behavior experiences. The grounded theory technique will produce data in the form of transcripts of in-depth interviews, which are illustrations of motivated behavior experienced by the respondents of the study.

Data obtained through meta-ethnography techniques will be analyzed and confirmed by data obtained through the technique of grounded theory. Analysis was performed back and forth to achieve satisfactory understanding (to reach saturation) in answering the research question. Thus the techniques of meta-ethnography and grounded theory are integrated in the process of analyzing data through open coding, axial coding and selective coding. The integration of these two techniques, as a multi-method approach, is hereafter called the meta-ethnographical-grounded-theory approach.

The conclusion formulated through meta-ethnographical-grounded-theory analysis, then performed as a hypothesis to be tested. The hypothesis testing is done through 
a thought experiment study. The thought experiment was conducted among university students. There were four studies conducted, with numbers of participants for each study being: 51, 40, 82, and 54 students. Participants were second year students, so that they were familiar with the learning process in the university.

Treatments for these thought experiment studies are scenarios concerning class situations, which characteristics are varied in terms of probability for success. There are three themes of the scenarios: (1) grading style (applied in two studies); (2) teaching style; and (3) class assignment design.

The procedure of the study is as follows: (1) participants are introduced to five scenarios of class situations; (2) participants are asked to rate the scenarios based on how much they like each of them; (3) participants are asked to rate the scenarios based on the strength of their tendency to choose; (4) participants are asked to rate the scenarios based on how strong they invoke motivation to learn, using a multiple choice scale; (5) participants are asked to rate the scenarios based on how strong they invoke motivation to learn, using a forced choice scale. Procedure (2) and (3) measure motivation as a choice, while procedure (4) and (5) measure motivation as a force or motivational force.

\section{Results}

After reinterpretation of the constructs that are believed to trigger motivation, five themes are formulated, each of which has distinctive psychological characteristics. These themes are explored one by one along with thematic logic that gives the arguments for the uniqueness of each theme. The five themes that emerged were named according to the nature of their psychological characteristics, namely: (1) urge, (2) freedom to choose, (3) challenge, (4) incentive, and (5) meaning.

Urge is an internal force that drives individuals to act. Urge includes the constructs of instinct, needs deprivation, revenge, and interest. Freedom to choose is characterized by situations that enable individuals to act without depending to others. It comprises the constructs of autonomy, independence, selfregulation, and self-determination. Challenge is a stimulation from the environment that triggers individuals to respond. Six constructs have this characteristic, i.e. difficult goal, demand, inequity, trust, responsibility, and competition. Incentive is something that is received as a consequence of the individual behavior, which attracts the individual to continue or redo what is done before. Incentive includes reward, constructive feedback, support, and achievement. The fifth theme is meaning, which is the intrinsic value of certain behavior so that it is worth doing. Meaning includes enjoyment, self-efficacy, self-actualization, contribution, and valence.

The five themes, which emerged as the result of open coding analysis, are motivational sources. Further analysis was undertaken through axial coding to integrate these themes in order to develop a dynamic model of motivation. Axial coding is done by exploring the nature of relationships of each motivational source with other motivational sources. The nature of these relationships is represented by vector constructs, i.e. constructs that have magnitude and direction.

This kind of reasoning is also known as the process theory of motivation, a theoretical perspective that focuses on explaining the process between variables. If content theories explain "what" is responsible for the 
emergence of motivation, process theories explain "how" the variables relate to each other to ignite motivational force. For example, urge is a source of motivation that has the characteristic of "push." A vector construct that corresponds to "push" is "drive," so urge is a source of motivation that drive other source so that it is activated. In this case urge drive freedom to choose to be active. On the other hand, freedom to choose has the capability to control urge, and so on. The result of axial coding analysis is illustrated in Figure 3 as an integrated human motivation model.

\section{Table 1. Summary of Constructs Related to Motivational Force}

\begin{tabular}{|c|c|c|}
\hline Themes & Constructs & Psychological Characteristics \\
\hline Urge & $\begin{array}{l}\text { Instinct } \\
\text { Need deprivation } \\
\text { Revenge } \\
\text { Interest }\end{array}$ & Internal forces that drive individual to act. \\
\hline $\begin{array}{l}\text { Freedom } \\
\text { to choose }\end{array}$ & $\begin{array}{l}\text { Autonomy } \\
\text { Independence } \\
\text { Self-determination } \\
\text { Self-regulation }\end{array}$ & $\begin{array}{l}\text { A situation that enables individual to act } \\
\text { without depending to others. }\end{array}$ \\
\hline Challenge & $\begin{array}{l}\text { Difficult goal } \\
\text { Demand } \\
\text { Inequity } \\
\text { Trust } \\
\text { Responsibility } \\
\text { Competition }\end{array}$ & $\begin{array}{l}\text { Stimulation from the environment that } \\
\text { triggers individual to respond. }\end{array}$ \\
\hline Incentive & $\begin{array}{l}\text { Reward } \\
\text { Constructive feedback } \\
\text { Support } \\
\text { Achievement }\end{array}$ & $\begin{array}{l}\text { Something that is received as consequences } \\
\text { of the individual behavior, which attracts } \\
\text { the individual to continue or redo } \\
\text { what is done before. }\end{array}$ \\
\hline Meaning & $\begin{array}{l}\text { Enjoyment } \\
\text { Self-efficacy } \\
\text { Self-actualization } \\
\text { Contribution } \\
\text { Valence }\end{array}$ & $\begin{array}{l}\text { Intrinsic values of certain behavior so that } \\
\text { it is worth doing. }\end{array}$ \\
\hline
\end{tabular}




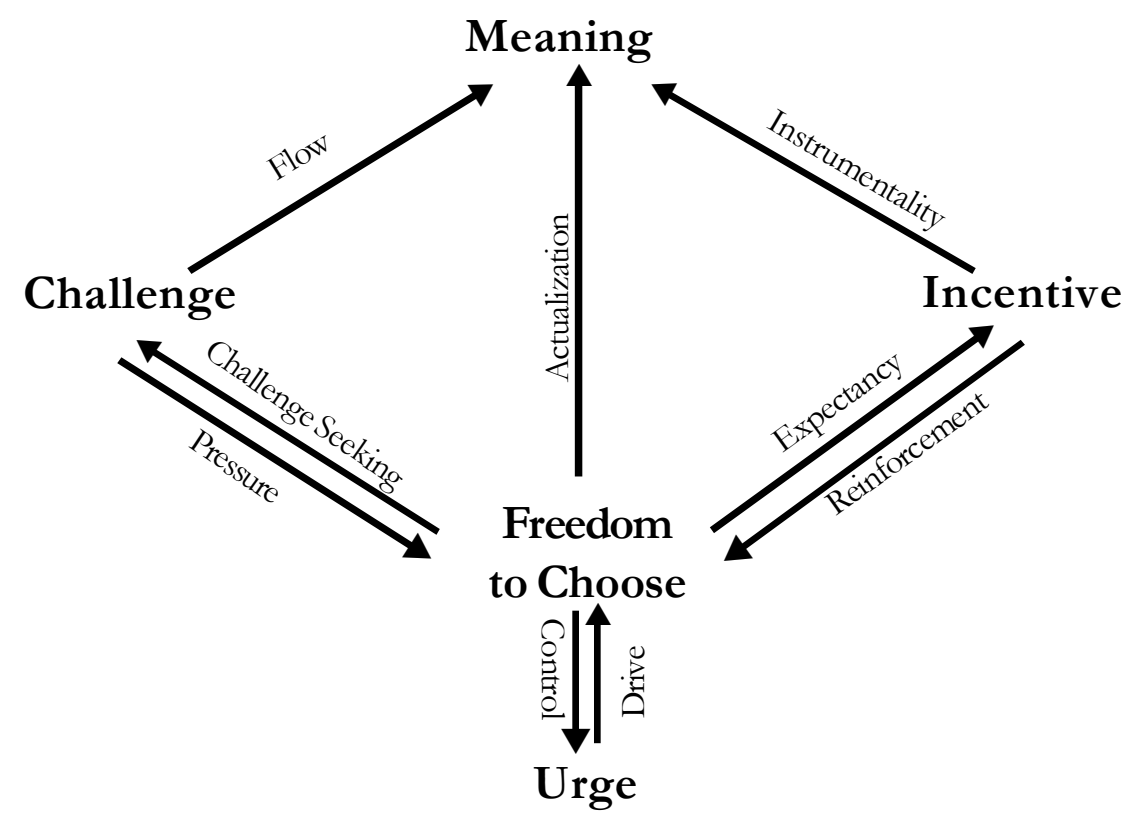

The formulation of the human motivation model still leaves one problem. The explanation provided by the human motivation model is still limited to the dynamics of the motivational sources. Further questions that need to be answered are, how does the motivational sources ignite motivational force, under what conditions, and how it is structured. Further analysis will explore and map the components and structure of the force, which in this paper is called the "anatomy of the force."

The method in conducting the deeper analysis to address these problems is selective coding. Selective coding is a method on qualitative data analysis to find a central phenomenon of the issues under study. Central phenomenon, in this case, is the essence of all phenomena that have been discussed in the human motivation model. Each theme that has been described in the model is explored in more depth (scrutinized), to identify the most fundamental psychological characteristics that are responsible for the dynamics of motivated behavior.
To do scrutiny on these themes, several layers of questions on "why," "what," "when," and "how," are posed to the situations that occur on each theme. The process of questioning is considered sufficient (saturated) when answers are repeating, or cycle back to previous answers. For example, why does urge drive an individual to act? Because it poses a threat to existence, if you do not fulfill your needs you won't survive. Thus, there is a risk of survival. People always have unfulfilled needs, but yet are not always motivated, so when do they motivate? Motivational force emerges when there is an opportunity. Although it is not always certain, but as long as there is hope, opportunity will be worth pursuing.

The result of the selective coding argues that all of the motivational sources within the human motivation model possess three fundamental psychological characteristics, i.e. risk avoidance, uncertainty tolerance, and hope reliance. Thus the essence of motivational force is the presence of risk, uncertainty, and hope. These basic ingredients of 
motivational force are intertwined with one another so that they trigger (ignite) the force to act, a power to act.

The dynamic interaction of risk, uncertainty, and hope is illustrated in Figure 4 as an atom-like relationship between electron, proton, and neutron. Therefore, it is called an atomic theory of motivation, which means a theory on the basic ingredients of motivational force. The three components that are integrated as a structure of motivational force are also called "the anatomy of the force."
Anatomy of the force explains what and how motivational force emerges within individual. It is also explains when any motivational sources become active and effective in invoking motivational force.

To be able to predict the strength of motivational force that works in an individual, the three elements (risk, uncertainty, and hope) need to be taken into account in an integrative formula. In other words, the strength of motivational force is the product of the interaction of these three essential ele-

Figure 4. Anatomy of the Force as "The Atomic Theory of Motivation"

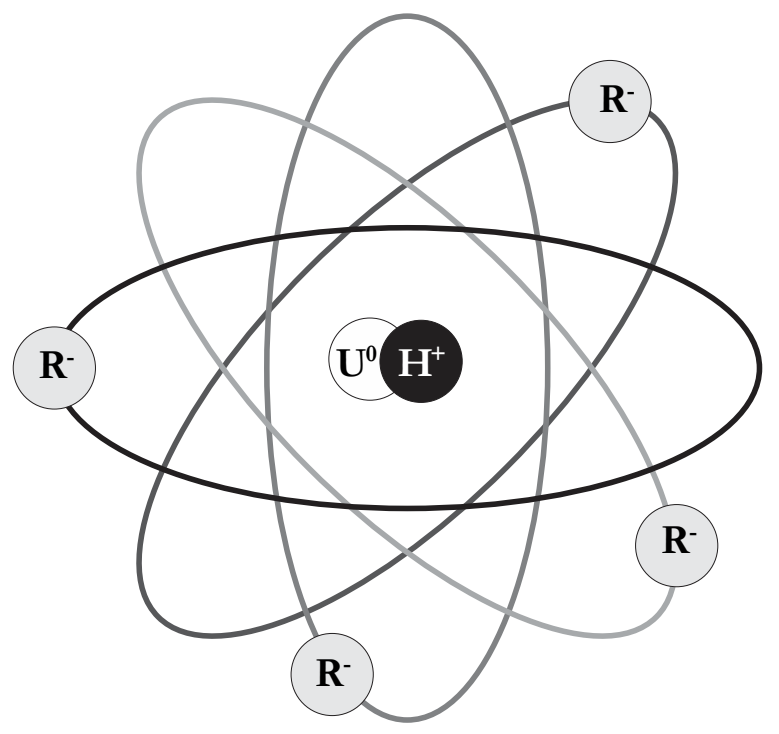

Figure 5. Hypothetical Profile of the Strength of the Force

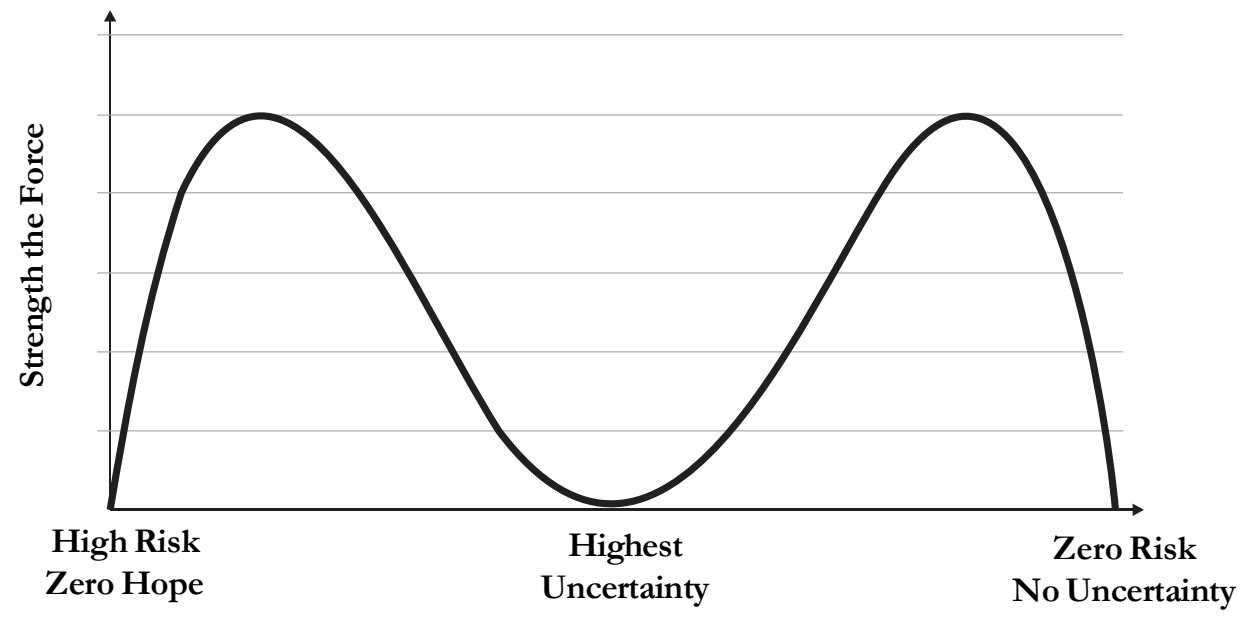


ments of risk, uncertainty, and hope. Interaction of the three elements must reside in a certain area of balance, because if there were an extreme imbalance, it would weaken the motivational force. The principle of "balance" is in line with the results of the study by Carroll and Alexandris (1997) who examined the interactive relationship between "perception of constraints" with "strength of motivation."

To measure a construct we need to apply mathematical logic. From the perspective of mathematical logic, hope and risk are inversely proportional, i.e. the greater the risk the smaller the hope, and vice versa. When there are both hope and risk, there will be uncertainty as well. When the magnitude of risk and hope are equal, then there is a 50-50 chance, a condition that has the highest or maximum level of uncertainty. The maximum or minimum conditions of each of these three elements are extreme situations that lead to weak or absence of motivational force.

Using that logical explanation, the strength of the force can be plotted to a profile, which illustrates the variability or fluctuation of motivational force as a result of the interaction between risk, hope, and uncertainty. The hypothetical profile is shown in Figure 5.

The profile shows three extreme positions where the strength of motivational force is near zero. These conditions are: (1) when there is no hope or maximum risk, which is identical to a condition of self-helplessness (Seligman 1990); (2) when there is maximum uncertainty (50-50 chance), when an individual becomes fatalistic; and (3) when there is no risk, that also means no uncertainty, a situation when individuals are in a comfort zone. On the other hand, the profile also shows twin peaks that indicate two situations of optimum strength for motivational forces. These situations have the psychological characteristics of: (1) optimum challenge, when risk is higher than hope; and (2) optimum opportunity, when hope is stronger than risk. The mathematical equation for the profile is as follows:

\section{Strength of the Force $=$ (Risk-Hope $)^{2}$ x Uncertainty}

Up to this point, there are still two more steps in order to complete the theory building. First, it is necessary to integrate the human motivation model and the anatomy of the force into one conceptual understanding. This one conceptual understanding is the expected final result of the selective coding analysis, which is called the central phenomenon. If we understand that there are a human motivation model and an anatomy of the force, what could be the one central phenomenon underlying this motivational dynamics? What is expected as a result of further analysis is a single statement that can explain the whole phenomenon of motivational force, which includes the human motivation model and anatomy of the force.

Second, the proposition of the strength of the force needs to be confirmed by behavioral indicators. How does the formula applied to real life events? How can we collect data to support this theoretical proposition? In order to answer these questions, the thought experiment is conducted. The thought experiment provides opportunity to test a theory by simultaneously refutes the theories that exist, and build a new theory through a process known as "mutual exclusion" (Wikipedia 2010).

Before presenting the results of the thought experiment, the following paragraphs 
explain the further selective coding analysis to reach the understanding of the central phenomenon. The analysis start with posing a question concerning the anatomy of the force, "if anatomy of the force is about integrated process of the emergence of the force, so what is that process called?" In other words, "what is the underlying phenomenon of risk, uncertainty, and hope?”

Risk avoidance, uncertainty tolerance, and hope reliance indicate something concerning human existence. If an individual is in fact always concerned with risk, uncertainty, and hope in their life, it means that they have no firm and certain fate for their existence. This phenomenon shows the vulnerability of human beings. On the other side, a human being also possesses freedom to choose, the central point of the human motivation model. This paradox of existence leads to the behavioral dynamics of utilizing freedom to choose to compensate for human vulnerability. In compensating for their vulnerability, a human being is pursuing something to hold on to. Something or someone that can help one to gain stability is called "an anchor" (Google dictionary 2010). Thus, the purpose of these behavioral dynamics is searching for anchors. Anchors create a psychological state of balance and stability.

Anchors are something that one can rely on in facing the uncertain future, avoiding risk, and providing hope. Anchors can be categorized into materials, self, others, and believing in virtues. For those who believe in God, virtues themselves are anchored to God. Therefore, God is the ultimate anchor. It is only logical, for those who believe, that the ultimate power of God is the perfect anchor, upon which a human being can rely without any doubt. Relying on the ultimate power of God will enable a peaceful psychological state in an individual, and at the same time provide fearless strength of motivational force as well. Figure 6 illustrates the layer of anchors in its ideal structure, which will provide authentic happiness and great strength of motivational force.

Figure 6. Layers of Anchors

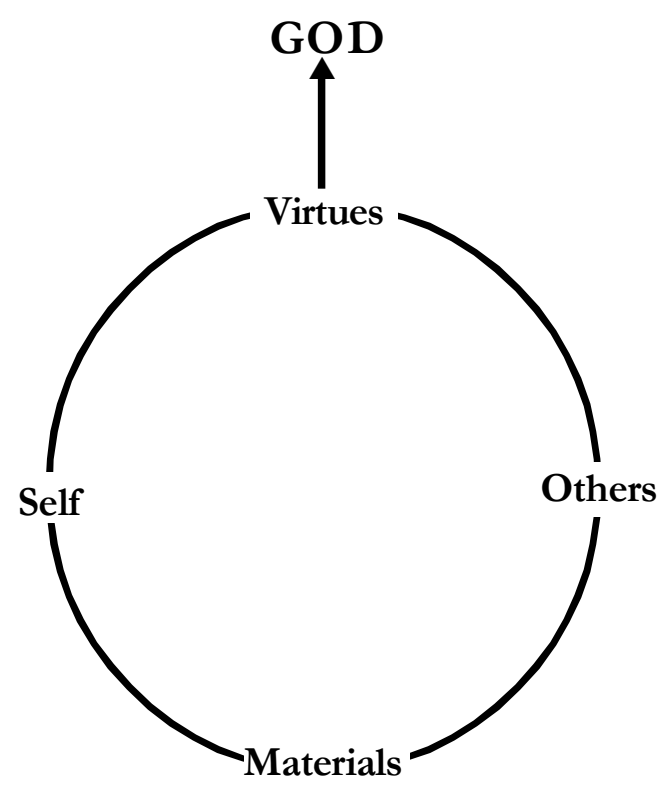




\section{Figure 7. In search for Anchors}

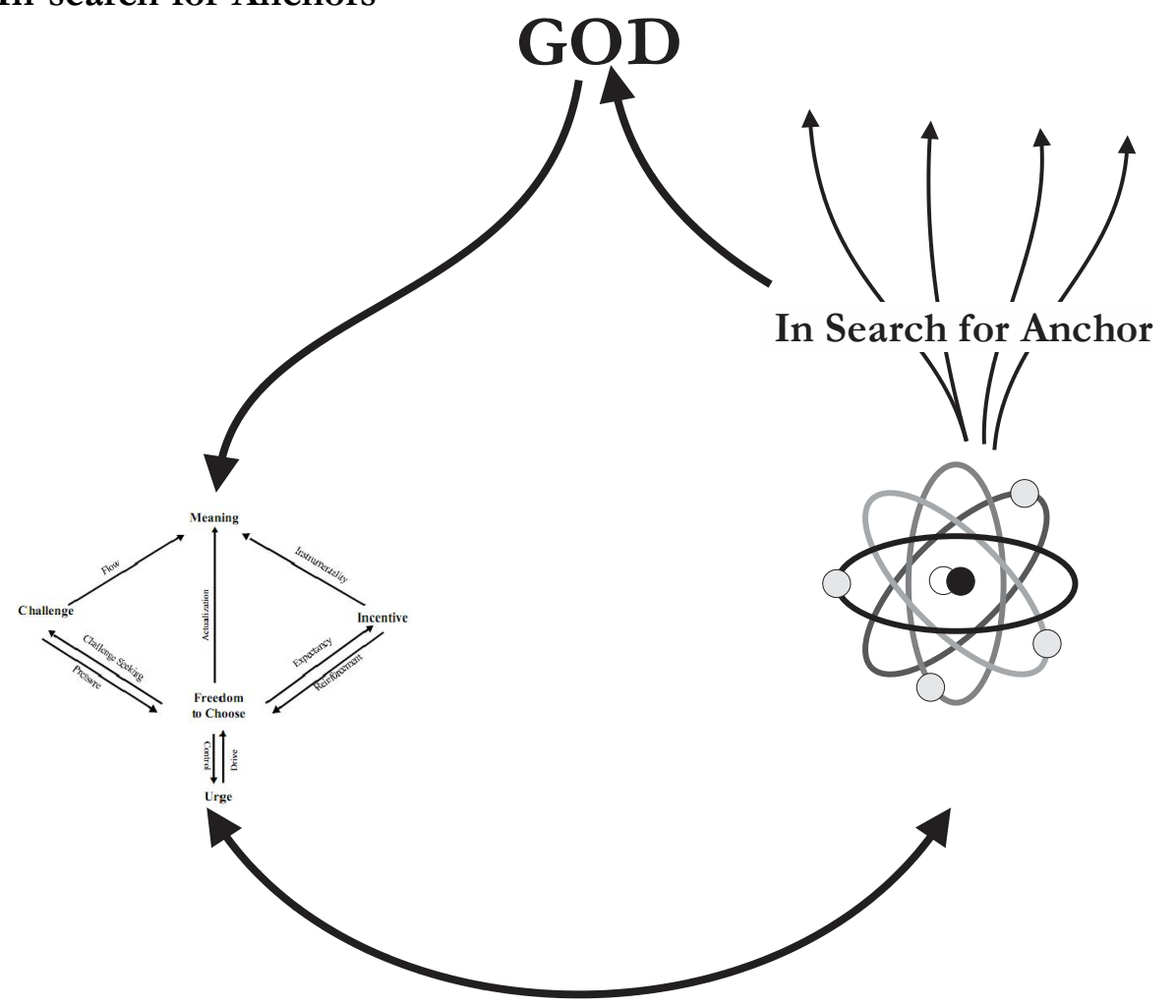

A problem arises when the structure of anchors within an individual is shifted or incomplete. Those people who "play god" might also put God as their anchor, but they put "self" to be in direct relationship with God instead of "virtues." If an individual does this, they automatically put "virtues" under "self," meaning that they make "virtues" to submit to the "self," and "others" as the object to be manipulated by "self."

If individuals do not believe in God, their layer of anchors is like a floating circle, which swings up and down and creates a psychological state of relentless confusion. At some point in time, they will be very certain of themselves, but at other times they will feel so helpless and confused about life. The happiness that they sometimes feel is illusive, not authentic. The motivational force that emerges within them is up and down, and cannot be relied on.
Figure 7 illustrates the summary of the new theory of motivational force. The final result for this study, which is aimed at building an integrated theory of motivational force, is called "In search for anchors: the fundamental motivational force in compensating for human vulnerability."

The overall dynamics of human behavior from the perspective of this theory are as follows. A human being as a creature of God is granted a freedom to choose to lead their life within the dynamic of human motivation model. Human freedom is the overt psychological characteristic that is innate in every individual. However, there is another side of human nature in terms of their future existence, which is characterized by risk, uncertainty, and hope. This covert characteristic of human being indicates the vulnerability of their existence. Consciously or not, individuals realize this paradox of existence 
Gadjah Mada International Journal of Business -September-December, Vol. 14,No.3, 2012

Table 2. Summary of Friedman Test for Significance of the Strength of the Force Profile

\begin{tabular}{lllll}
\hline \multirow{2}{*}{ No } & Scenario & N & \multicolumn{2}{c}{$\mathbf{X}^{2}$} \\
\cline { 4 - 5 } & & & $\mathbf{1}^{*}$ & $\mathbf{2}^{*}$ \\
\hline 1 & Grading style (study 1) & 51 & $39,4^{* *}$ & $15,3^{* *}$ \\
2 & Grading style (study 2) & 40 & $36,0^{* *}$ & $43,9^{* *}$ \\
3 & Teaching style & 82 & $58,5^{* *}$ & $85,6^{* *}$ \\
4 & Class assignment design & 54 & $20,6^{* *}$ & 4,4 \\
\hline
\end{tabular}

$* 1=$ measured by multiple choice; $2=$ measured by forced choice

** Significance at the level of $\mathrm{p}<0,01$

Figure 8. Empirical Profiles as the Results of Multiple-Choice Scale

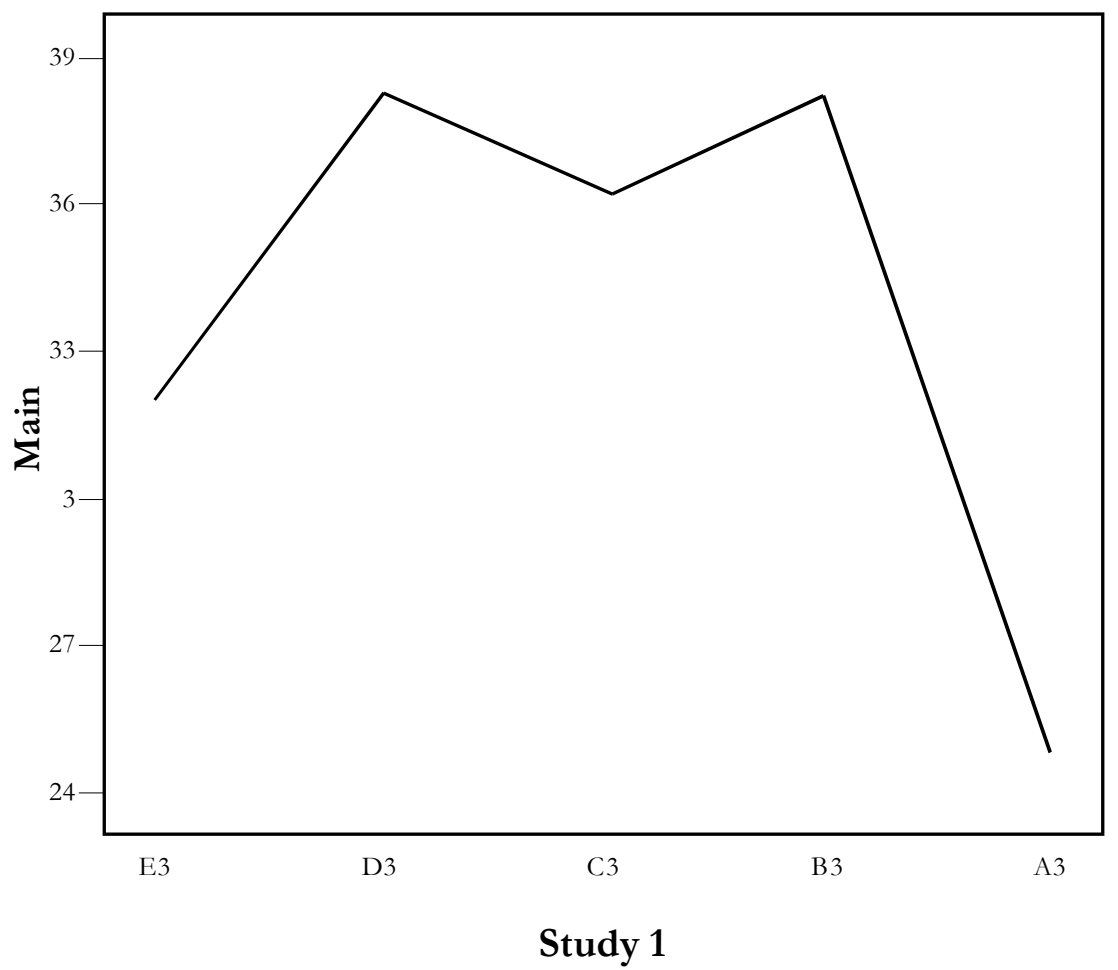


Riyono et al.

Figure 8 (Continued)

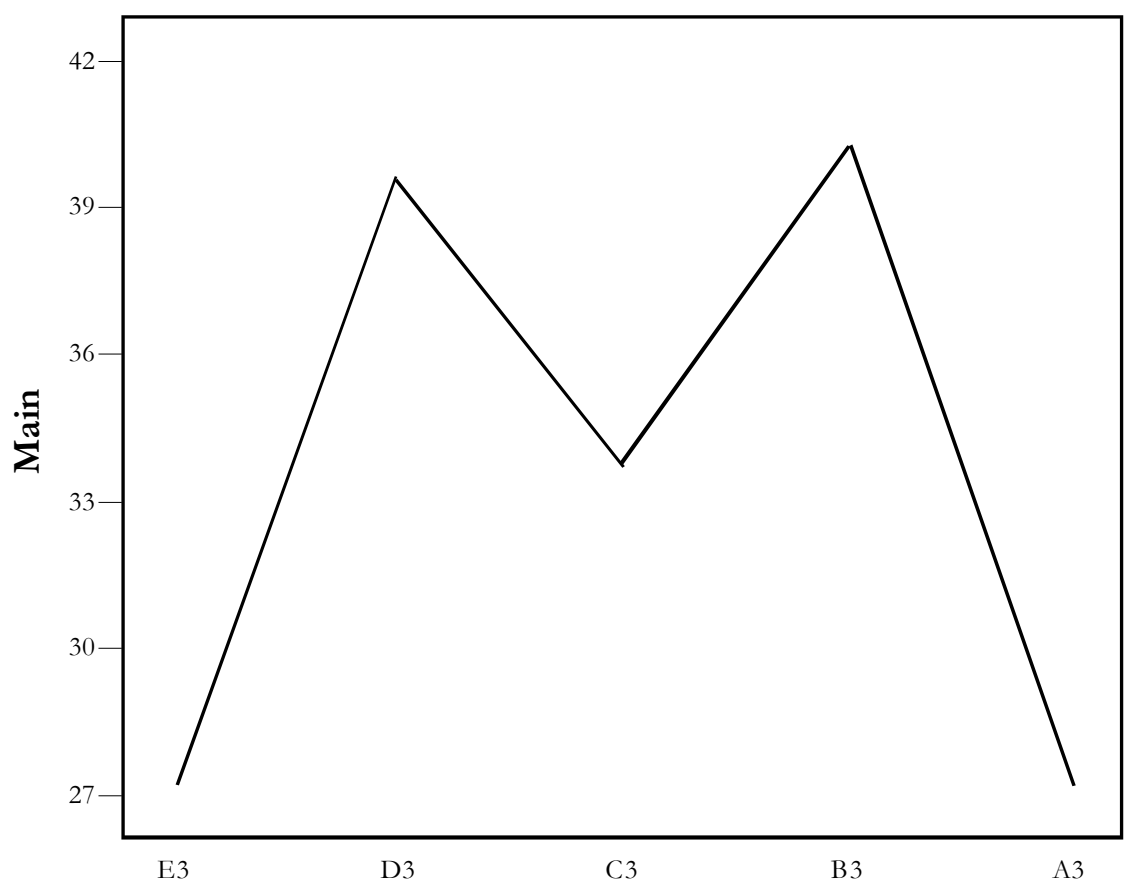

Study 2

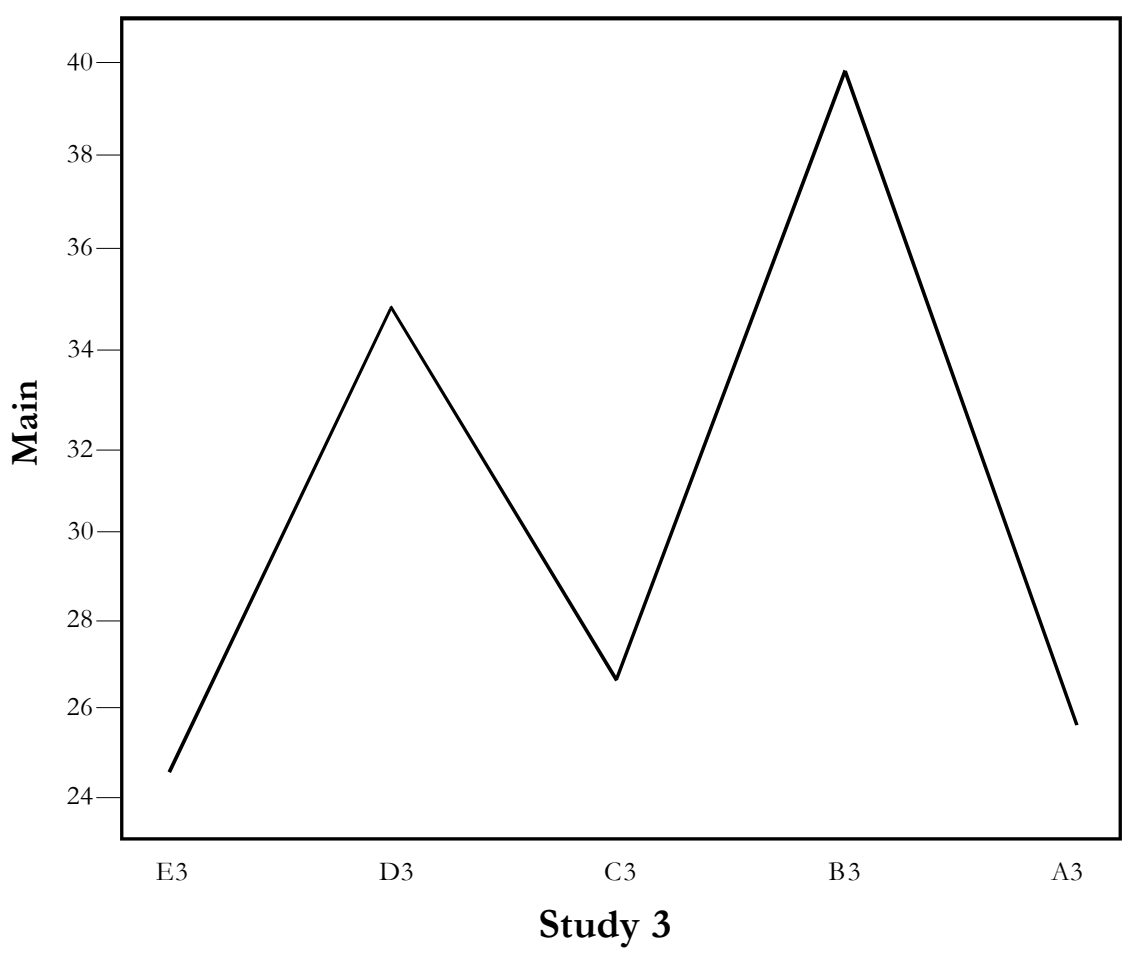


Gadjah Mada International Journal of Business -September-December, Vol. 14,No.3, 2012

\section{Figure 8 (Continued)}

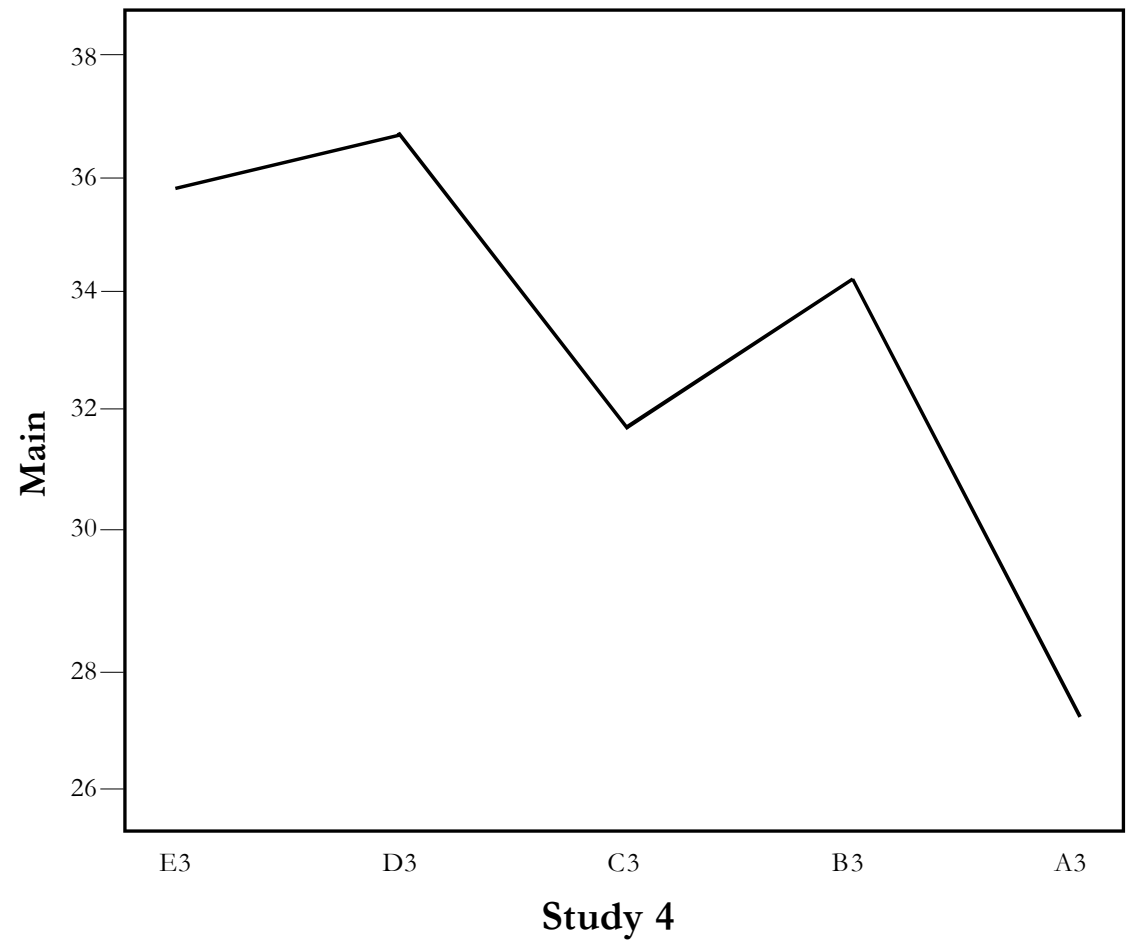

Figure 9. Empirical Profiles as the Results of Forced-Choice Scale

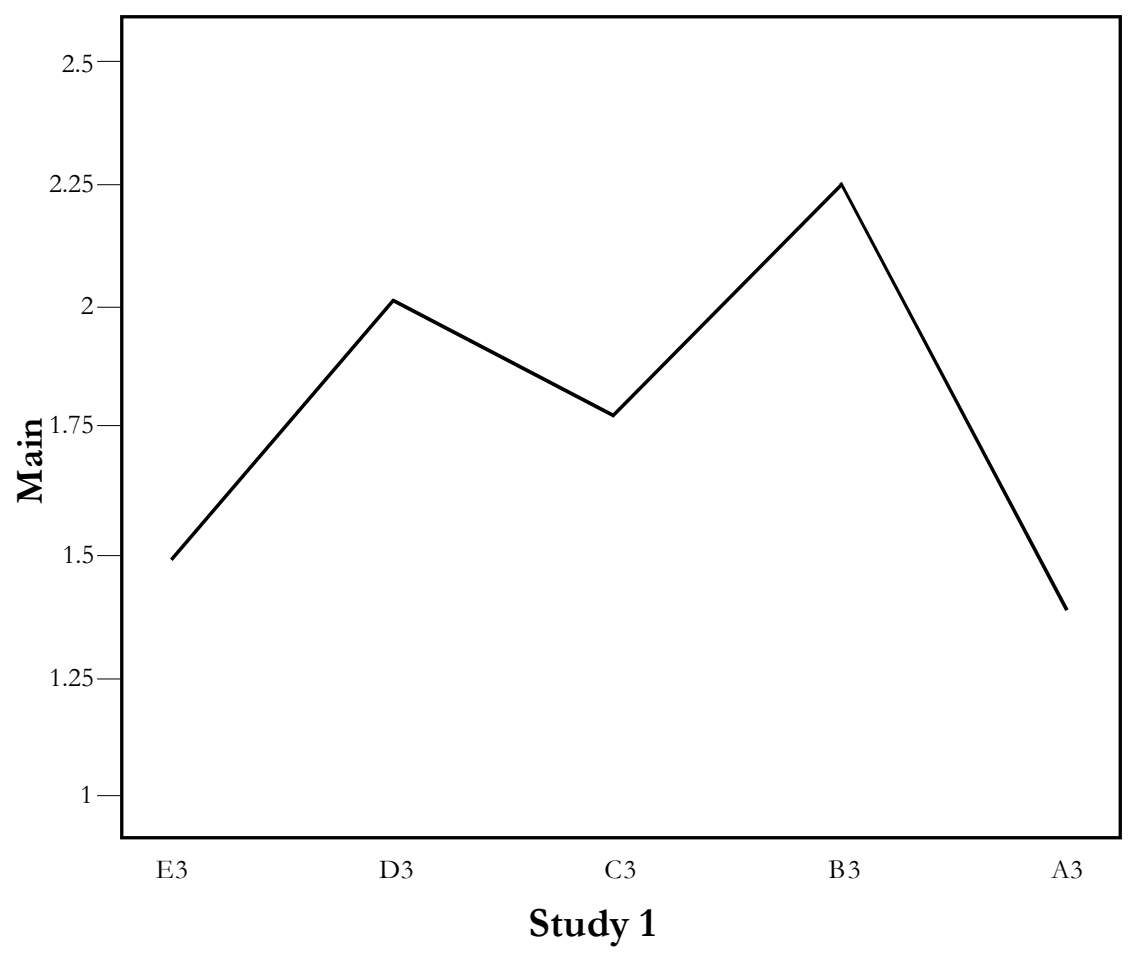


Riyono etal.

Figure 9 (Continued)
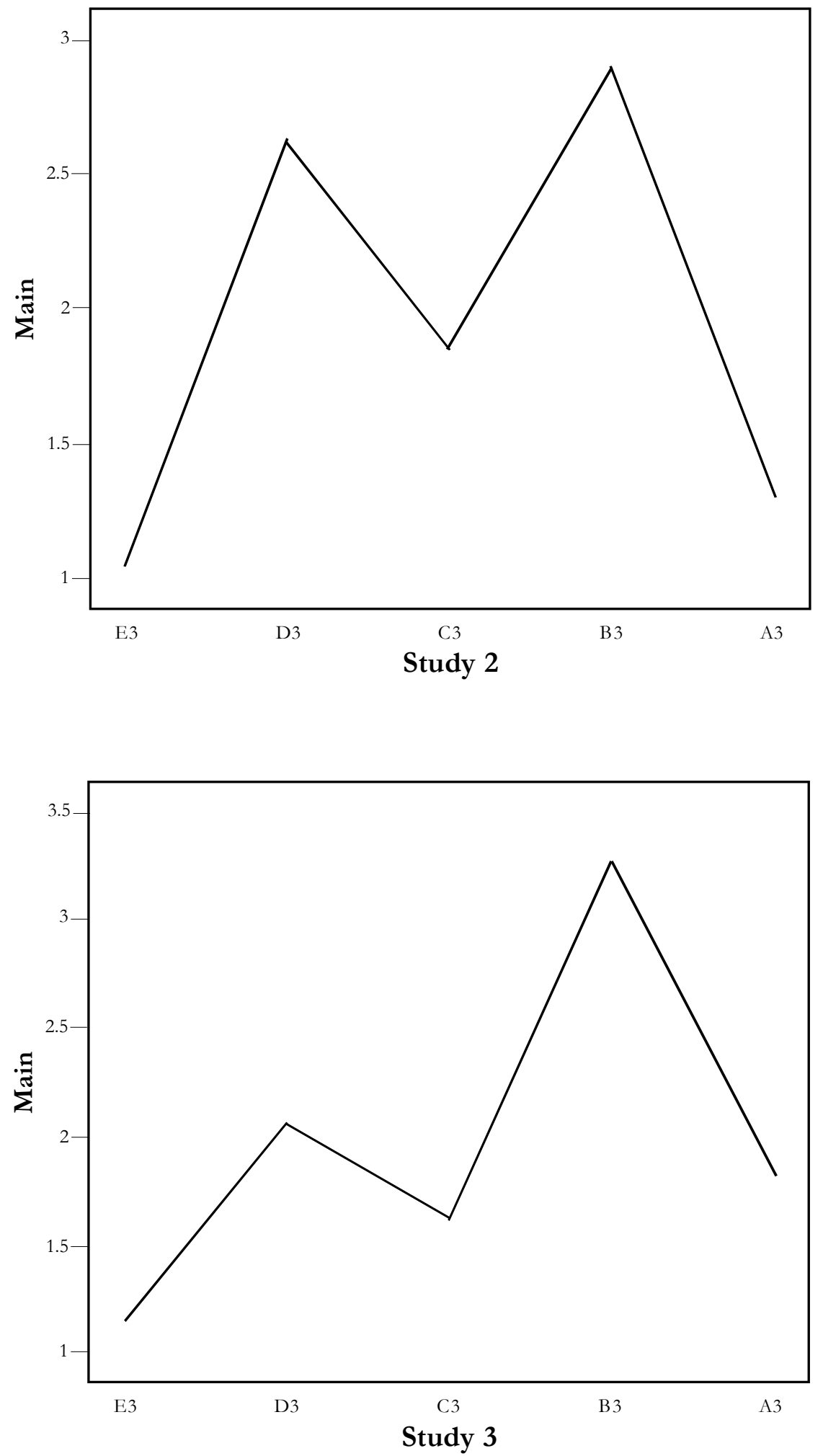


\section{Figure 9 (Continued)}

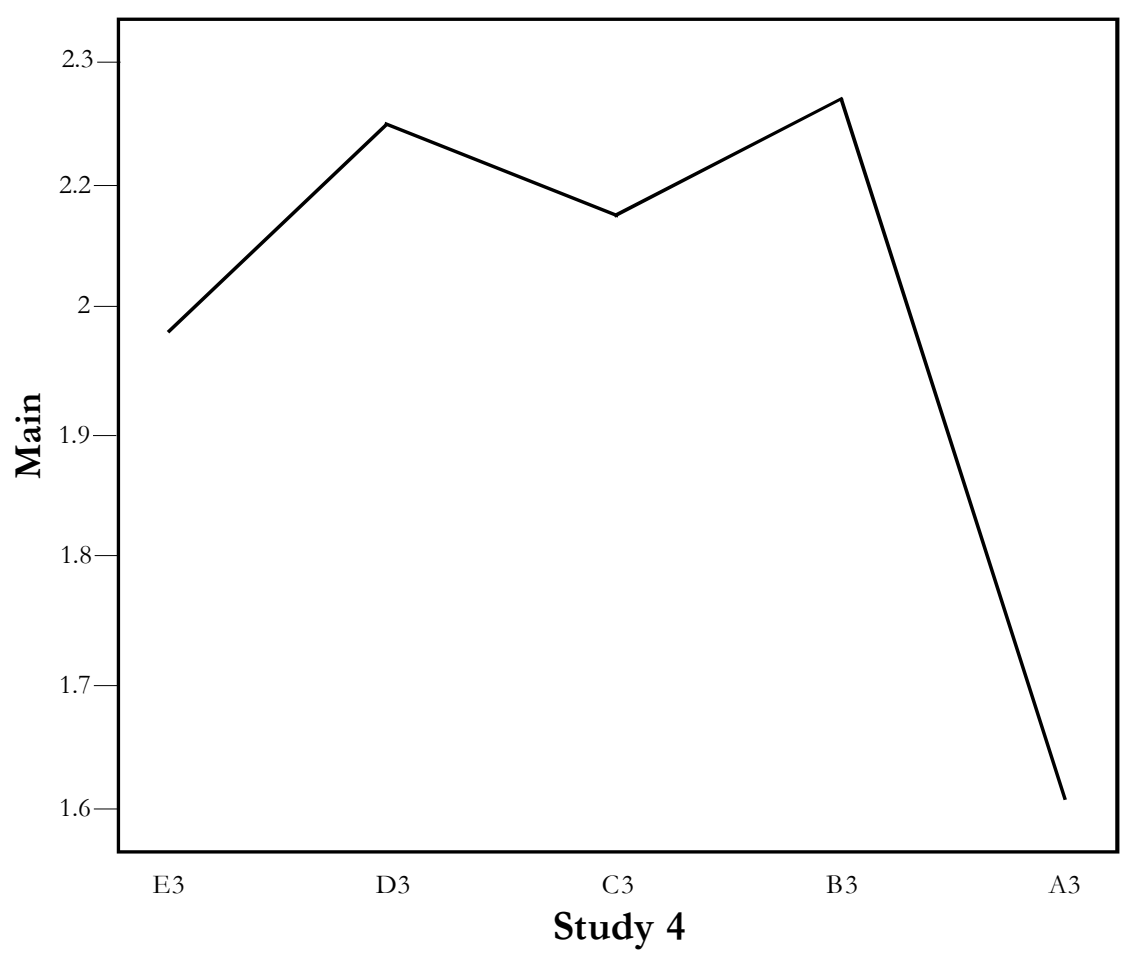

within themselves. This paradox creates instability within the human psyche that ignites a force to compensate. In compensating for the instability of their existence, human beings are always in search for anchors, which guide their day-to-day behavior in their life. Happiness or despair is determined by how an individual selects and structures their anchors.

Since the theory building is complete, the next paragraphs report the results of the thought experiment in testing the hypothesis on the formula of the strength of the force. The overall results of the four studies support the hypothesis, as shown in Table 2. There are eight empirical profiles of strength of the force resulting from the four studies. All profiles, except one, show significant trends according to the Friedman test (Friedman 1937).
The empirical profiles of the strength of the force are shown in Figure 8 and Figure 9. Figure 8 shows the empirical profiles as the results of multiple-choice scale, while Figure 9 shows the empirical profiles as the results of forced-choice scale.

The empirical profiles show slightly different trends compared to the hypothetical profile. The results of Studies 1, 2, and 3 consistently indicate that the point of optimum opportunity is higher than the point of optimum challenge. They also show that the points of 50-50 chance are not as low as the hypothesis. Although it is also significant in terms of the trend of the profile, Study 4's result shows a different shape of a profile.

Figure 9, which shows the results of a forced-choice scale measurement, confirms the results measured by the multiple-choice scale (Figure 8). However, Study 4 at this 
point does not pass the significance test, although it resembles the shape of the results of the other studies. Further analysis is conducted to find the source of the anomaly in Study 4. Content analysis on the reasons to the ratings is done upon the data collected in Study 4. There is a theme emerges in the reasons or explanation of the ratings for every scenario that is posed in Study 4. On every explanation of the ratings, the participants of the study make a statement that correspond to the existence of hope. Here are some statements concerning the scenarios of class assignment in study 4 :

"the more difficult the assignment the more effort is needed, such as study harder"

"the more burden we have the more serious we need to be"

"the more demanding a task the more it push me to study harder to give the best."

\section{Discussion}

This study has succeeded in building a new theory of motivational force, which has three levels of analysis. The first level, which is the most overt in nature, is the reconstruction of contemporary theories of motivation into a holistic-dynamic-integrative human motivational model. On the second level of analysis, this study has developed an understanding of the other side of human life, which is more covert in nature, in a form of anatomy of the force that comprises risk, uncertainty, and hope. On the final analysis, at a more philosophical level, it is found that there is an underlying dynamic of human behavior, which is called in search for anchors.

On the second phase of the study, the hypothesis derived from the theory of the anatomy of the force was tested and supported by empirical data. However, the em- pirical results suggest that there is a refinement needed for the theory of the strength of the force. The bolt message conveyed by the empirical data is that out of the three elements of the anatomy of the force, hope stands out to be the most significant factor that is responsible for the emergence of the force. To comply with what the empirical data suggest, the formula of the strength of the force is modified as follows:

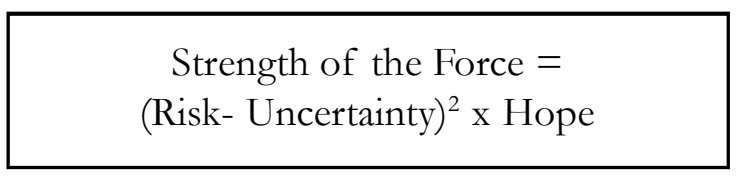

The modified formula states that: (1) Hope is the most significant factor of motivational force, i.e. when there is no hope there will be no motivational force as well; (2) Risk and uncertainty are interacting with each other as when uncertainty reaches the maximum, it will be the same as the risk, and therefore it will hamper the motivational force; (3) Risk and uncertainty are prerequisites for motivational force, and they are twoin-one in nature, i.e. when there is no risk there will be no uncertainty, vice versa. Therefore, the absence of either one will extinguish the motivational force. The new profile of the strength of the force as a result of the modified formula is illustrated in Figure 10.

The final profile of the strength of the force shows five points that indicate five psychological states related to the magnitude of the force. Psychological state I is characterized by the absence of hope. It is the psychological state of learned helplessness. Psychological state II is characterized by a high level of risk and uncertainty, with sufficient amount of hope. This situation is called the psychological state of optimum challenge. The psychological state III is characterized by a situation with a 50-50 chance. It does not matter what you do, the chance is $50-50$. 
Figure 10. The Modified Profile of the Strength of the Force Based on Empirical Testing

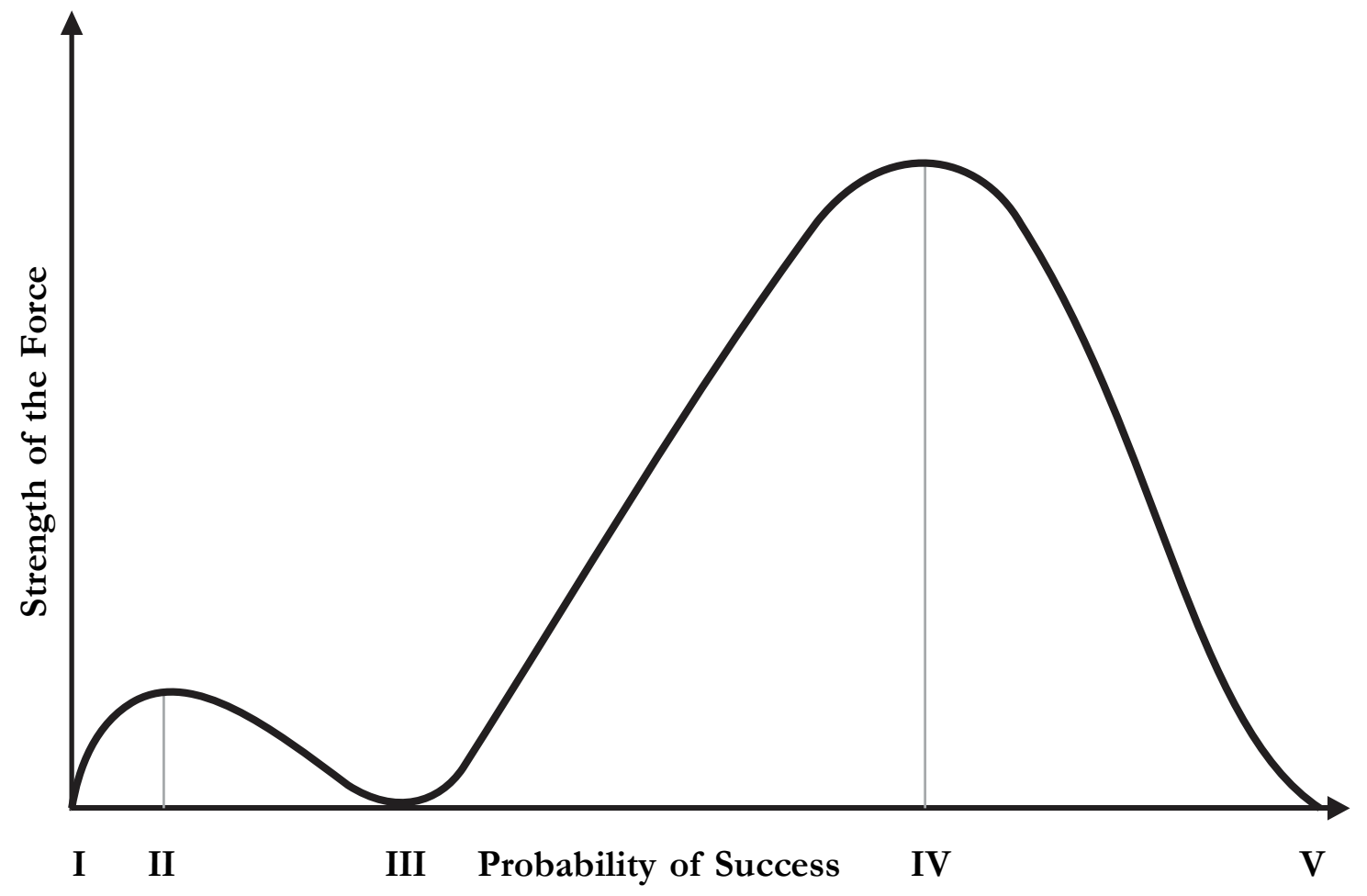

It is called the psychological state of fatalist. The highest point in the profile (IV) is called the psychological state of optimum opportunity. It is characterized by high hope with sufficient amount of risk and uncertainty that create excitement. The psychological state $\mathrm{V}$ is characterized by the absence of risk, which is known to be the psychological state of comfort zone.

The concept of RUH (Risk, Uncertainty, Hope) is quite practical for describing, explaining, and predicting situations in terms of their motivational force capability. For example when an organization initiates a motivational program, it should contain RUH as the basic ingredients of the prescription to work. When parents are having problems with their children's motivation to study, they could analyze whether studying for the kid contained RUH or how strong does the RUH chemistry exist.

\section{Conclusion}

This study has formulated a new perspective and a working theory of human motivation. Since the new theory is built based on the existing theories and empirical data, it is a meta theory which focuses on the essence of motivational dynamics. The newly formulated theory is named 'RUH theory', which stands for Risk, Uncertainty and Hope as the fundamental dynamics of motivational force. In one sentence the theoretical proposition can be stated as follows: "Motivation will emerge when a person or a group of people forsee that there is risk to avoid, and at the same time they have hope to pursue under an uncertain situation."

The application of RUH Theory in the organizational setting is very practical and yet fundamental. For example when a new policy is developed to change organizational cul- 
ture, the management should consider whether the new culture possess the nuance of RUH in the eyes of the employee. In other words, management should communicate that there are risks to avoid if they remain in the existing organizational culture, so that they have a reason to change. On the other hand management also needs to admit that they cannot guarantee that the change will be smooth with no obstacles or problems along the way. However, management also has to show confidence not based on certainty or promise, but based on hope, which is a strong belief that "We" can acheive a better tomorrow together.

This study is focusing on theory-building, therefore it is limited to conceptual discussion. The practical application of the theory needs to be studied further. On the methodological perspective, further studies are going to apply laboratory experiments or field experiements, in order to gain empirical support for the theory. The topics and context of the further studies will include motivation in a work setting, family relationships, and social interaction.

\section{References}

Atkinson, J. W. 1957. Motivational determinants of risk-taking behavior. Psychological Review 64 (6): 359372.

Carroll, B., and K. Alexandris. 1997. Perception of constraints and strength of motivation: Their relationship to recreational sport participation in greece. Journal of Leisure Research 29 (3): 279-299.

Cascio, W. F., and H. Aguinis. 2008. Research in industrial and organizational psychology from 1963 to 2007: changes, choices, and trends. Journal of Applied Psychology, 93(5), 1062-1081.

Deci, E.L., Koestner, R., and R. M. Ryan. 1999a. A meta-analytic review of experiment examining the effects of extrinsic rewards on intrinsic motivation. Psychological Bulletin 125 (6): 627-668.

Dipboye, R. L., C. S. Smith, and W. C. Howell. 1994. Industrial and Organizational Psychology, An Integrated Approach. Fort Worth: Harcourt Brace College Publishers.

Durkheim, E., and M. Mauss. 1971. Note on the notion of civilization. Social Research 38 (4): 808-813.

Eisenberger, R. and J. Cameron. 1996. Detrimental effects of reward: reality or myth? American Psychologist 51 (11): 1153-1166.

Eisenberger, R., W. D. Pierce, and J. Cameron. 1999. Effects of reward on intrinsic motivation - negative, neutral, and positive: Comment on Deci, Koestner, and Ryan (1999). Psychological Bulletin 125 (6): 677-691.

Friedman, M. 1937. The use of ranks to avoid the assumption of normality implicit in the analysis of variance. Journal of the American Statistical Association 32 (200): 675-701.

Gioia, D. A., and E. Pitre. 1990. Multiparadigm perspectives on theory building. Academy of Management Review 15 (4): 584-602.

Google Dictionary. 2011. Anchor. Retrieved from http://www.google.com/dictionary?langpair=en\%7Cen\&q= anchor\&hl=en\&aq $=\mathrm{f}$ 
Hoekman, K., J. McCormick, and K. Barneet. 2005. The important role of optimism in a motivational investigation of the education of gifted adolescent. The Gifted Child Quaterly 49 (2): 99-110.

Khaldun, Ibn. 1377. Muqaddimab: An Introduction of History (F. Rosenthal, Trans.). New Jersey: Princeton University Press.

Komaki, J. 1981. A behavioral view of paradigm debates: let the data speak. Journal of Applied Psychology, 66 (1): 111-112.

Komaki, J. L. 1986. Toward effective supervision: an operant analysis and comparison of managers at work. Journal of Applied Psychology 71 (2): 270-279.

Komaki, J. L., R. L. Collins, and P. Penn. 1982. The role of performance antecedents and consequences in work motivation. Journal of Applied Psychology 67 (3): 334-340.

Komaki, J., K. D. Barwick, and L. R. Scott. 1978. Behavioral approach to occupational safety pinpointing and reinforcing safe performance in a food manufacturing plant. Journal of Applied Psychology 63 (4): 434-445.

Komaki, J., A. T. Heinzmann, and L. Lawson. 1980. Effect of training and feedback: Component analysis of a behavioral safety program. Journal of Applied Psychology 65 (3): 261-270.

Komaki, J. L., M. L. Desselles, and E. D. Bowman. 1989. Definitely not a breeze: extending an operant model of effective supervision to teams. Journal of Applied Psychology 74 (3): 522-529.

Komaki, J. L., S. Zlotnick, and M. Jensen. 1986. Development of an operant-based taxonomy and observational index of supervisory behavior. Journal of Applied Psychology 71 (2): 260-269.

Kondo, Y. 1991. Human Motivation: A Key Factor for Management. Tokyo: 3A Corporation.

Latham, G. P., and J. J. Baldes. 1975. The "practical significance" of Locke's theory of goal setting. Journal of Applied Psychology 60 (1): 122-124.

Latham, G. P., and C. C. Pinder. 2005. Work motivation theory and research at the dawn of the twentyfirst century. Annual Review of Psychology 56: 485-516.

Lepper, M. R., J. Henderlong, and I. Gingras. 1999. Understanding the effects of extrinsic rewards on intrinsic motivation - uses and abuses of meta-analysis: Comment on Deci, Koestner, and Ryan (1999). Psychological Bulletin 125 (6): 669-676.

Lindenberg, S. 2001. Intrinsic motivation in a new light. KYKLOS 54: 317-342.

Locke, E. A., and G. P. Latham. 1990. A Theory of Goal Setting and Task Performance. Englewood Cliffs, New Jersey: Prentice Hall.

Locke, E. A. 1980. Latham versus Komaki: A tale of two paradigms. Journal of Applied Psychology 65 (1): 16-23.

Maslow, A. H. 1943. A theory of human motivation. Psychological Review 50: 370-396.

McClelland, D. 1961. The Achieving Society. New York: The Free Press.

McClelland, D. 1966. That urge to achieve. THINK Magazine 32 (6): 19-23.

McClelland, D. 1987. Human Motivation. New York: Cambridge University Press.

Naisbitt, J., and D. Naisbitt. 2010. China's Megatrends: 8 Pilar yang Membuat Dabsyat China (H. Prasetyo, Trans.). Jakarta: Gramedia.

Noblit, G. W., and R. D. Hare. 1988. Meta-Ethnography: Synthesizing Qualitative Studies. Newbury Park: Sage Publications. 
Payne, R. 1970. Factor analysis of a Maslow-type need satisfaction questionnaire. Personnel Psychology 23: 251-268.

Petri, H. L., and J. M. Govern. 2004. Motivation: Theory, Research, and Application ( $5^{\text {th }}$ ed.). Betmont: Thomson, Wadsworth.

Schulze, G. G., and B. Frank. 2003. Deterrence versus intrinsic motivation: experiemental evidence on the determinants of corruptibility. Economics of Governance 4: 143-160.

Seligman, M. E. P. 1990. Learned Optimism. New York: Alfred A. Knopf, Inc.

Skinner, B. F. 1953. Science and Human Behavior. London: The Free Press.

Smith, A. 1776. An Inquiry into the Nature and Causes of The Wealth of Nations. London.

Strauss, A. L., and J. Corbin. 1990. Basics of Qualitative Research: Grounded Theory Procedures and Technique. Newbury Park: Sage Publications.

Thompson, B. R., and H. J. Thornton. 2002. The transition from extrinsic to intrinsic motivation. Education 122 (4): 785-792.

Vansteenkiste, M., and E. L. Deci. 2003. Competitively contingent rewards and intrinsic motivation: can loosers remain motivated. Motivation and Emotion, 27 (4): 273-299.

Vroom, V. H. 1964. Work and Motivation. New York: John Wiley and Sons, Inc.

Wanous, J. P., T. L. Keon, and J. C. Latack. 1983. Expectancy theory and occupational/organizational choices: a review and test. Organizational Behavior and Human Performance 32: 66-86.

Weber, M. 1930. Protestant Ethics and The Spirit of Capitalism. London: HarperCollins Academic.

Wiest, D. J., E. H. Wong, Cervantes, L. Craik, and D. A. Kreil. 2001. Intrinsic motivation among regular, special, and alternative education high school students. Adolescence 36 (141): 111-126.

Wikipedia. 2010. Thought Experiment. Retrieved from: http://en.wikipedia.org/wiki/Thought_experiment.

Wood, R. E., B. M. Kakabeeke, S. Debowski, and M. Frese. 2000. The impact of enactive exploration on intrinsic motivation, strategy, and performance in electronic search. Applied Psycology: an International Review 49 (2): 263-283.

Xiang, P., A. Chen, and A. Bruene. 2005. Interactive impact of intrinsic motivators and extrinsic rewards on behavior and motivation outcomes. Journal of Teaching in Physical Education 24: 179-197. 
